Jarosław Matysiak

(Polska Akademia Nauk Archiwum w Warszawie)

dr, jarekm@man.poznan.pl

ORCID ID: 0000-0002-0934-5916

\title{
Materiały do dziejów Archiwum Państwowego w Poznaniu w świetle spuścizn z zasobu PAN Archiwum w Warszawie Oddział w Poznaniu
}

Sto pięćdziesiąta rocznica utworzenia Archiwum Państwowego w Poznaniu, przypadająca w marcu 2019 r., oraz mijająca w kwietniu tegoż roku setna rocznica oficjalnego przejęcia Archiwum przez władze polskie z rąk pruskich są doskonałą okazją do pochylenia się nad materiałami źródłowymi o dziejach tej zasłużonej dla historii i kultury polskiej instytucji.

Kwestię materiałów źródłowych, dotyczących poznańskiego Archiwum omówił już w 1968 r. były jego dyrektor Czesław Skopowski w artykule Materiały do dziejów Archiwum Państwowego w Poznaniu, który ukazał się w tomie pięćdziesiątym "Archeionu”. Autor, w związku ze zbliżającym się stuleciem istnienia placówki, przedstawił $\mathrm{w}$ krótkim zarysie ważniejsze materiały związane z funkcjonowaniem tej instytucji. W szczególności uwzględnił on rękopiśmienne źródła archiwalne i źródła drukowane oraz opracowania dotyczące Archiwum i jego zasobu ${ }^{1}$.

W ciągu minionego półwiecza ilość materiałów źródłowych (rękopiśmiennych i drukowanych) oraz publikacji dotyczących dziejów interesującej nas instytucji znacząco wzrosła. Wszelkiego rodzaju opracowania, artykuły, referaty i inwentarze archiwalne, które ukazały się drukiem w ciągu minionych pięćdziesięciu lat, niewątpliwie poszerzyły stan badań nad dziejami Archiwum Państwowego w Poznaniu.

Materiały i źródła znajdują się nie tylko w zbiorach tej jednostki, ale także w innych placówkach kulturalnych i naukowych, m.in. w zasobach PAN Archiwum w Warszawie Oddział w Poznaniu.

${ }^{1}$ C. Skopowski, Materiały do dziejów Archiwum Państwowego w Poznaniu, "Archeion” 1968, t. 50, s. $143-155$. 
PAN Archiwum w Warszawie Oddział w Poznaniu zajmuje się gromadzeniem, opracowywaniem i udostępnianiem materiałów źródłowych do dziejów nauki polskiej. Przechowuje ono akta z placówek PAN oraz gromadzi materiały pochodzenia prywatnego w postaci spuścizn po uczonych z Poznania i Wielkopolski. Wśród tych zespołów archiwalnych na uwagę zasługują spuścizny pracowników Archiwum Państwowego w Poznaniu: dyrektorów - Kazimierza Kaczmarczyka (1878-1966), Czesława Skopowskiego (1906-1991) i Jana Szajbla (1926-1973) oraz kierownika Pracowni Konserwacji materiałów archiwalnych - Kazimiery Chojnackiej (1923-2010).

Działalność zawodowa i naukowa tych osób doczekała się już opracowania m.in. w postaci: prac magisterskich i doktorskich, biogramów, artykułów wspomnieniowych i okolicznościowych ${ }^{2}$. Dlatego w artykule omówione zostaną tylko ich spuścizny, ze szczególnym uwzględnieniem fragmentów dotyczących pracy w Archiwum Państwowym w Poznaniu.

${ }^{2}$ Zob.: Kazimierz Kaczmarczyk: Z żałobnej karty. Kazimierz Kaczmarczyk 1878-1966, „Archiwista. Biuletyn Stowarzyszenia Archiwistów Polskich” 1966, nr 3(6), s. 31; F. Paprocki, Prof. dr Kazimierz Kaczmarczyk (1878-1966) (wspomnienie pośmiertne), „Kronika Miasta Poznania” 1967, t. 35, nr 1, s. 127-131; I. Radtke, Kazimierz Kaczmarczyk 1878-1966, "Studia i Materiały do Dziejów Wielkopolski i Pomorza" 1968, t. 9, z. 2, s. 187-189; C. Skopowski, Kazimierz Kaczmarczyk 3 II 1878-6 IV 1966, „Archeion” 1967, t. 47, s. 277-280; tamże, bibliografia prac; K. Tymieniecki, Kazimierz Kaczmarczyk (1878-1966), „Roczniki Historyczne” 1967, r. 33, s. 283-285; C. Skopowski, Kazimierz Kaczmarczyk 1878-1966, [w:] Życiorysy polskich archiwistów poznańskich i skład osobowy z dnia 8 III 1969 roku, Poznań 1969, s. 21-27; A. Marciniak, Kazimierz Kaczmarczyk, [w:] Wielkopolski słownik biograficzny, Warszawa-Poznań 1981, s. 306-307; I. Radtke, Kazimierz Kaczmarczyk, [w:] Stownik biograficzny archiwistów polskich, t. 1, 1918-1984, Warszawa-Łódź 1988, s. 93-95; S. Nawrocki, Kazimierz Kaczmarczyk (1878-1966), [w:] Wybitni historycy wielkopolscy, red. J. Strzelczyk, Poznań 1989, s. 295-302; J. Matysiak, Kazimierz Kaczmarczyk (1878-1966). Archiwista $i$ historyk, "Archiwista Polski" 2006, nr 2, s. 37-49; tegoż, Kazimierz Kaczmarczyk (1878-1966). Archiwista i historyk, praca doktorska napisana pod kierunkiem S. Żerki, Poznań 2010, repozytorium.amu.edu.pl/handle/10593/692 (dostęp: 06.11.2019); tegoż, Kazimierz Kaczmarczyk (18781966). W pięćdziesiąta rocznice śmierci - wspomnienie, "Przegląd Archiwalno-Historyczny" 2016, t. 3, s. 333-338; B. Piotrowski, Kazimierz Kaczmarczyk (1878-1966), [w:] Stownik biograficzny powstańców wielkopolskich 1918-1919, red. A. Czubiński, B. Polak, Poznań 2002, s. 143; Kaczmarczyk Kazimierz, [w:] Poczet członków Poznańskiego Towarzystwa Przyjaciót Nauk 1857-2007, red. A. Pihan-Kijasowa, Poznań 2008, s. 199. Czesław Skopowski: S. Nawrocki, Czesław Skopowski (1906-1991), „Poznański Rocznik Archiwalno-Historyczny” 1993, r. 1, s. 93-97; tegoż, Czestaw Skopowski (9 VI 1906-22 XII 1991), „Archeion” 1995, t. 94, s. 366-374, tegoż, Czestaw Skopowski, [w:] Stownik biograficzny archiwistów polskich, t. 2, Warszawa 2002, s. 160-161. Jan Szaj bel: Jan Szajbel, "Archiwista” 1973, r. 9, z. 4/5, s. 45-46; S. Nawrocki, Jan Szajbel (19 IX 1926 - 12 XI 1973), "Archeion” 1975, t. 62, s. 325-327, tegoż, Szajbel Jan, [w:] Stownik biograficzny archiwistów polskich, t. 1, Warszawa 1988, s. 211-212; A. Marciniak, Wspomnienie o doktorze Janie Szajblu (1926-1973), „Biuletyn Archiwum Polskiej Akademii Nauk” 2007, nr 48, s. 223-230. Kazimiera Chojnacka, Kazimiera Chojnacka (1923-2010), [w:] Poczet członków Poznańskiego Towarzystwa Przyjaciót Nauk 1857-2007, pod. red. A. Pihan-Kijasowej Poznań 2008, s. 114; P. Wojciechowski, Kazimiera Chojnacka, „Archeion” 2010, t. 111, s. 520-523; tegoż, Kazimiera Chojnacka (1923-2010), „Poznański Rocznik Archiwalno-Historyczny” 2012, r. 15, s. 280-282; tegoż, Chojnacka Kazimiera, [w:] Stownik biograficzny Archiwistów Polskich, t. 3, Warszawa 2017, s. 51-52. 
Pierwszą, najstarszą i najobszerniejszą, jest spuścizna Kazimierza Kaczmarczyka, archiwisty, historyka, regionalisty, wydawcy źródeł, dyrektora Archiwum Państwowego w Poznaniu w latach 1925-1953. Spuściznę zakupiło Archiwum Polskiej Akademii Nauk w 1967 r. od wdowy po profesorze Józefy Kaczmarczykowej ${ }^{3}$. Objętość nabytych materiałów wynosiła około $4 \mathrm{mb}$ akt. W 1997 r., po zakupieniu przez Oddział poznański spuścizny księgarza i wydawcy Jana Jachowskiego, wyłączono z jego materiałów około $2 \mathrm{mb}$ materiałów dotyczących Kazimierza Kaczmarczyka i włączono do jego spuścizny. Z Biblioteki Zakładu Narodowego im. Ossolińskich pozyskano mikrofilmy korespondencji z lat 1896-1958, którą w 1954 r. dyrektor poznańskiego Archiwum podarował do zbiorów Ossolineum.

W 2009 r. Elżbieta Grabarczyk - wnuczka Kazimierza Kaczmarczyka przekazała w darze 0,28 mb akt, a w 2010 r. sprzedała Archiwum 39 fotografii, przedstawiających dyrektora i jego współpracowników z okresu międzywojennego oraz gmach Archiwum przed 1939 r.

Prace porządkowo-inwentaryzacyjne prowadzone były z przerwami w latach 1967- 2002 przez Annę Marciniak oraz w latach 2006-2010 przez Jarosława Matysiaka. Rozmiar zespołu wynosi 5,50 mb. Spuścizna oznaczona sygnaturą P III-35 zawiera materiały z lat 1687-1968. Podzielono ją na osiem zasadniczych grup.

Okres pracy Kazimierza Kaczmarczyka jako dyrektora Archiwum Państwowego w Poznaniu odzwierciedlają archiwalia zgromadzone $\mathrm{w}$ grupie II - Materiały działalności organizacyjno-naukowej, wydawniczej, redakcyjnej i społecznej (jednostki archiwalne 156-235) oraz w grupie III - Materiały biograficzne (jednostki archiwalne 236-258). Są to wszelkiego rodzaju dokumenty, sprawozdania, pisma okólne, notatki i korespondencja.

${ }^{3}$ Wartość naukowa materiałów Kazimierza Kaczmarczyka była już doceniana za jego życia. W 1956 r. dyrektor Archiwum PAN dr Zygmunt Kolankowski wystąpił z propozycją zakupu spuścizny od byłego dyrektora Archiwum Państwowego w Poznaniu. W liście wysłanym przez Kolankowskiego do Kaczmarczyka czytamy m.in.: „Ponieważ Archiwum PAN gromadzi wszelkiego rodzaju materiały, które mogłyby stanowić źródło do historii nauki Polskiej, przeto reflektowałoby na nabycie zebranych przez Sz. Pana materiałów. Z uwagi na celowość zabezpieczenia całości materiałów jako jednorodnego kompleksu dokumentacyjnego związanego bezpośrednio z Osobą jego Twórcy - Archiwum najchętniej zakupiłoby wszystkie zebrane i wytworzone przez Sz. Pana materiały / zarówno rękopisy gotowych prac, jak i notatki, wypisy, wyciągi, korespondencję naukową z instytucjami oraz z poszczególnymi uczonymi i t. p./, z tym, że na życzenie Sz. Pana Archiwum PAN mogłoby zapewnić Mu korzystanie z części, które byłby niezbędne dla dalszej Jego pracy". Zob. fragment pisma dyrektora Archiwum PAN dr. Zygmunta Kolankowskiego do K. Kaczmarczyka L. dz. Arch. 302/56 z 12 maja 1956 r. Polska Akademia Nauk Archiwum w Warszawie Oddział w Poznaniu (dalej PANAWOP), Materiały Kazimierza Kaczmarczyka (1878-1966), sygn. P III-35, j.a. 260, k. 44. Z ówczesnej propozycji Archiwum PAN Kaczmarczyk nie skorzystał, traktując swoją spuściznę jako materiał warsztatowy dla własnych badań. 
Zasadniczo materiały te dzielą się na archiwalia z lat 1922-1939 i 19451953, przy czym materiałów z okresu międzywojennego jest stosunkowo niewiele. Spośród nich na uwagę zasługuje m.in. jednostka archiwalna (dalej j.a.) 158, zawierająca opis gmachu Archiwum, przedstawiająca jego personel, a także wykazy spisów, inwentarzy, skorowidzów i zasobu z 1922 r. oraz wykaz nabytków z lat 1920-1937, zestawiony w 1947 r. ${ }^{4}$ W j.a. 159 znajduje się m.in. liczący 74 pozycji wykaz ważniejszych prac Archiwum Państwowego w Poznaniu, dotyczący ustalenia tytułu własności przedrozbiorowych majątków królewskich znajdujących się na Pomorzu i w Wielkopolsce, przeprowadzonych w latach 1920-1924 na rzecz polskiej delegacji, działającej przy Komisji Odszkodowań (Commission de Reparations) w Paryżu w pierwszej połowie lat dwudziestych ${ }^{5}$.

$\mathrm{Z}$ okresu międzywojennego na uwagę zasługuje jeszcze j.a. 171, która zawiera materiały dotyczące udziału Kazimierza Kaczmarczyka w pracach Komisji Odbiorczo-Zdawczej do wymiany akt z Niemcami, oraz j.a. 172, gdzie znajduje się dokumentacja jego udziału w pracach Delegacji Polskiej do wykonania polsko-austriackiego układu archiwalnego z października 1932 r. ${ }^{6}$

Obszerniejsza jest dokumentacja jego pracy na stanowisku kierownika, a następnie dyrektora Archiwum Państwowego w Poznaniu w latach 19451953.

W j.a. 160 zgromadzono materiały dotyczące m.in. odbudowy Archiwum ze zniszczeń wojennych, rewindykacji zasobu archiwalnego, korespondencji z Ministerstwem Oświaty (któremu przez pewien czas po 1945 r. podlegały Archiwa Państwowe) i innymi instytucjami, sprawozdania z czynności urzędowych i wykazy. Na uwagę zasługuje korespondencja dotycząca sprawy rozbiórki północnego skrzydła gmachu byłego Sądu Apelacyjnego w Poznaniu, który został przekazany na potrzeby Archiwum. Koncepcje władz miejskich, które poprzez rozbiórkę części gmachu planowały wyeksponować fragmenty baszty i murów miejskich, zostały mocno skrytykowane przez dyrektora poznańskiego Archiwum. W piśmie do Ministerstwa Oświaty Wydziału Archiwów Państwowych z sierpnia 1949 r. tak oceniał pomysł włodarzy miejskich: „Głównymi argumentami przemawiającymi za nami powinna być ta okoliczność, że mury gmachu są w dobrym stanie, burzenie ich pociągnęłoby duże koszta, co wobec akcji oszczędnościowej jest marnowaniem funduszów państwowych, zburzenie skrzydła podcięłoby rozwój Archiwum w przyszłości i wywołałoby potrzebę budowania nowego gmachu na pomieszczenie na-

${ }^{4}$ PANAWOP, Materiały Kazimierza Kaczmarczyka (1878-1966), sygn. P III-35, j.a. 158, Archiwum Państwowe w Poznaniu.

${ }^{5}$ Tamże, j.a. 159, Archiwum Państwowe w Poznaniu .

${ }^{6}$ Tamże, j.a. 171, Komisja Odbiorczo-Zdawcza do wymiany akt z Niemcami; j.a. 172, Delegacja Polska do wykonania układu archiwalnego polsko-austriackiego. 
pływających akt"7. Logiczne i rzeczowe argumenty kierownika Archiwum nie zostały jednak wzięte pod uwagę i ostatecznie wyburzono część północnego skrzydła budynku.

W j.a. 161 znajdują się m.in.: protokoły zebrań i konferencji „produkcyjnych", sprawozdania, plany, okólniki oraz sprawy personalne - spisy pracowników, opinie, korespondencja ${ }^{8}$.

Kończąc omawianie spuścizny Kazimierza Kaczmarczyka, wspomnieć warto o materiałach, które znajdują się w grupie III spuścizny. Na uwagę zasługuje j.a. 245, zawierająca materiały z uroczystości jego pożegnania w Archiwum Państwowym w związku przejściem na emeryturę w kwietniu 1953 r. ${ }^{9}$, oraz j.a. 252, w której znajdują się fotografie dyrektora wraz ze współpracownikami ${ }^{10}$.

Następcą Kazimierza Kaczmarczyka na stanowisku dyrektora Archiwum Państwowego w Poznaniu został w maju 1953 r. Czesław Skopowski. Po rezygnacji ze stanowiska dyrektora placówki w styczniu 1972 r., został kierownikiem Zespołu naukowo-badawczego. Na emeryturę przeszedł w styczniu $1975 \mathrm{r}$.

Materiały Czesława Skopowskiego zostały zakupione od autora spuścizny przez PAN Archiwum w Warszawie w latach 1979 i 1980. W 1989 r. PAN Archiwum w Warszawie Oddział w Poznaniu otrzymało w darze od autora spuścizny kolejny fragment materiałów. Zespół został uporządkowany i zinwentaryzowany przez Jarosława Matysiaka, Justynę Świdzińską i Martynę Brembor w 2018 r. Został podzielony na sześć zasadniczych grup. Zawiera on materiały z lat 1916-1988. W PAN Archiwum w Warszawie Oddział w Poznaniu spuściźnie nadano sygnaturę P. III-66.

Archiwalia związane z Archiwum Państwowym w Poznaniu przechowywane w spuściźnie Czesława Skopowskiego znajdują się w grupie I Materiały działalności naukowej, w grupie II - Materiały działalności zawodowej, redakcyjnej, politycznej, związkowej, społecznej, oraz w grupie III - Materiały biograficzne.

W grupie pierwszej, w j.a. 2 znajduje się maszynopis pracy z poprawkami autorskimi pt. Z dziejów Archiwum Państwowego w Poznaniu. Wybór źró-

7 Tamże, j.a. 160, Archiwum Państwowe w Poznaniu, kopia pisma K. Kaczmarczyka z dnia 4 sierpnia 1949 r. L. dz. 392/2/49 do Ministerstwa Oświaty Wydział Archiwów Państwowych, k. 94.

${ }^{8}$ Tamże, j.a. 161, Archiwum Państwowe w Poznaniu.

${ }^{9}$ Tamże, j. a. 245. Uroczystość pożegnania w Archiwum Państwowym w Poznaniu 30 kwietnia $1953 \mathrm{r}$.

10 Tamże, j.a. 252, Praca w Archiwum Państwowym w Poznaniu, ze współpracownikami, ze zjazdów i konferencji. 
det z lat 1866-196511, a w j.a. 3-9 - maszynopis opracowania Dzieje Poznania i Województwa Poznańskiego (w granicach z 1974 r.). Informator o materiałach archiwalnych, t. $2^{12}$. W tej samej grupie znajduje się również j.a. 14, zawierająca materiały do dziejów Archiwum - wspomnienia byłych pracowników: Anieli Chosławskiej, Stanisława Prutkowskiego, życiorys i dorobek naukowy Kazimierza Kaczmarczyka, odpisy artykułu i korespondencji oraz fotokopie artykułów prasowych ${ }^{13}$.

W grupie II znajduje się łącznie czternaście jednostek archiwalnych, związanych z Archiwum poznańskim. Są to m.in.: j.a. 18, zawierająca spis zespołów archiwalnych przekazanych 31 stycznia 1952 r. do Ministerstwa Bezpieczeństwa Publicznego oraz wykaz najcenniejszych zespołów - stan z marca 1962 r. ${ }^{14}$; j.a. 19, w której zgromadzono wykazy wykonanych prac porządkowo-inwentaryzacyjnych i innych prac archiwalnych, a także zestawienia, bilanse, sprawozdania i informacje, z lat 1954-196915; j.a. 21, zawierająca Statut, zarządzenia wewnętrzne dyrektora, korespondencję z Naczelną Dyrekcją Archiwów Państwowych, wychodzącą i wpływającą, wraz z załącznikami, z lat 1954-1971 ${ }^{16}$, oraz j.a. 24, w której znajdują się materiały dotyczące działalności Komisji Metodycznej. Są to oceny zespołów porządkowanych przez pracowników archiwum - Irenę Radtke i Jana Szajbla z 1959 r. ${ }^{17}$

Interesujące materiały znajdują się $\mathrm{w}$ j.a. 22, zawierającej dokumentację dotyczącą działalności oświatowej i popularyzatorskiej ${ }^{18}$, w j.a. 27, która zawiera materiały związane z III Tygodniem Archiwów 21-27 października 1968 r. ${ }^{19}$, oraz w j.a. 29, w której zgromadzono dokumentację uroczystości z okazji jubileuszu stulecia Archiwum: scenariusz audycji telewizyjnej, wykazy osób, które otrzymały medale okolicznościowe, foldery, druki i koperty okolicznościowe, artykuły i wycinki prasowe oraz fotografie ${ }^{20}$.

Ciekawym źródłem do dziejów Archiwum Państwowego w Poznaniu w spuściźnie Czesława Skopowskiego jest j.a. 30, w której zgromadzono fotografie: budynków, biblioteki, pracowni mikrofilmów, magazynu ksiąg grodzkich i ziemskich, wystaw organizowanych przez Archiwum oraz pracowni-

${ }^{11}$ PANAWOP, Materiały Czesława Skopowskiego (1906-1991) P. III-66, j.a. 2, Z dziejów Archiwum Państwowego w Poznaniu. Wybór źródet z lat 1866-1965.

12 Tamże, j.a. 3-9, Dzieje Poznania i Województwa Poznańskiego (w granicach z 1974 r.). Informator o materiatach archiwalnych, t. 2.

${ }^{13}$ Tamże, j.a. 14, Archiwum Państwowe w Poznaniu.

${ }^{14}$ Tamże, j.a. 18, Archiwum Państwowe w Poznaniu.

15 Tamże, j.a. 19, Archiwum Państwowe w Poznaniu.

${ }^{16}$ Tamże, j.a. 21, Archiwum Państwowe w Poznaniu.

17 Tamże, j.a. 24, Archiwum Państwowe w Poznaniu.

${ }^{18}$ Tamże, j.a. 22, Archiwum Państwowe w Poznaniu.

${ }^{19}$ Tamże, j.a. 27, Archiwum Państwowe w Poznaniu.

${ }^{20}$ Tamże, j.a. 29, Archiwum Państwowe w Poznaniu. 
ków ${ }^{21}$. Informacje o Archiwum zawarte są także w jego wspomnieniach, które znajdują się w j.a. $50^{22}$.

W kolejnej spuściźnie - Jana Szajbla, następcy Czesława Skopowskiego także znajdują się materiały związane $\mathrm{z}$ Archiwum Państwowym w Poznaniu.

Jan Szajbel pełnił funkcję dyrektora Archiwum Państwowego w Poznaniu stosunkowo krótko - od stycznia 1972 r. do listopada 1973 r. Jego spuścizna została przekazana do PAN Archiwum w Warszawie Oddział w Poznaniu przez PAN Archiwum w Warszawie w latach 1974 i 1980. Została uporządkowana i zinwentaryzowana przez Jarosława Matysiaka i Mikołaja Woźnicę w 2017 r. Zawiera ona materiały z lat 1933-1973. Została podzielona na sześć zasadniczych grup. W PAN Archiwum w Warszawie Oddział w Poznaniu spuściźnie nadano sygnaturę P. III-54. Archiwalia związane z Archiwum Państwowym w Poznaniu, przechowywane w spuściźnie Jana Szajbla, znajdują się w grupie II - Materiały Działalności naukowej zawodowej, politycznej, związkowej, społecznej - łącznie sześć j.a.

Są to m.in.: sprawozdania $\mathrm{z}$ wykonanych prac, notatki do kwerend z lat 1957-1959, które znajdują się w j.a. $49^{23}$. J.a. 50 zawiera: spisy zespołów i zbiorów akt, materiały statystyczne dotyczące działalności Oddziałów Terenowych i Powiatowych Archiwów Państwowych woj. bydgoskiego, poznańskiego i zielonogórskiego, rozwój działalności Powiatowego Archiwum Państwowego w Gnieźnie, plany - zebrań pracowników w 1969 r. oraz naukowo-badawczy na lata 1971-1975, z lat 1957-197124. W j.a. 53 zgromadzona jest dokumentacja Komitetu Obchodów Stulecia Archiwum - projekt założeń do programu obchodów, program uroczystości, zaproszenie, program wystawy okolicznościowej, korespondencja, z lat 1968-196925. W j.a. 54 znajdują się materiały inwentaryzacyjne do dziejów wsi: instrukcja, tematyka, hasła ${ }^{26}$.

Ostatnim zespołem, w którym znajdują się materiały do dziejów Archiwum Państwowego w Poznaniu, jest spuścizna Kazimiery Chojnackiej, pracownika Archiwum od października 1955 r., a w latach 1981-1987 kierownika Pracowni Konserwacji materiałów archiwalnych.

Kazimiera Chojnacka przekazała swoją spuściznę poznańskiemu Oddziałowi Archiwum PAN w 2007 r. Archiwalia zostały uporządkowane i zinwentaryzowane przez Jarosława Matysiaka, Martynę Brembor i Justynę Świdzińską w 2018 r. Zespół zawiera materiały z lat 1890-2011. Został podzie-

\footnotetext{
${ }^{21}$ Tamże, j.a. 30, Archiwum Państwowe w Poznaniu.

22 Tamże, j.a. 50, Moje wspominki.

${ }^{23}$ PANAWOP, Materiały Jana Szajbla (1926-1973), P. III-54, j.a. 49. Archiwum Państwowe w Poznaniu.

24 Tamże, j.a. 50, Archiwum Państwowe w Poznaniu.

25 Tamże, j.a. 53, Archiwum Państwowe w Poznaniu.

${ }^{26}$ Tamże, j.a. 54, Archiwum Państwowe w Poznaniu.
} 
lony na osiem zasadniczych grup. W PAN Archiwum w Warszawie Oddział w Poznaniu spuściźnie nadano sygnaturę P. III-141.

Archiwalia związane z Archiwum Państwowym w Poznaniu przechowywane w spuściźnie Kazimiery Chojnackiej znajdują się w grupie II - Materiały działalności organizacyjno-naukowej, zawodowej, redakcyjnej, społeczno-politycznej - łącznie sześć j.a.

Są to m.in.: plany zebrań i pracy, zestawienia i sprawozdania wykonanych prac oraz notatki, które znajdują się w j.a. $29^{27}$. Dokumentacja pracy w zespołach naukowo-badawczych - wyciągi z planu i plany pracy, sprawozdania, notatki i korespondencja - zgromadzona została w j.a. 3128. Sprawozdania z podróży służbowych znajdują się w j.a. $32^{29}$, natomiast materiały dotyczące jubileuszów utworzenia Archiwum - foldery, druki i pocztówki okolicznościowe, artykuły i wycinki prasowe - zgromadzono w j.a. $33^{30}$.

Na uwagę zasługuje także j.a. 51, w której zgromadzono 78 fotografii z lat 1958-1986, dokumentujących działalność Archiwum. Są to m.in.: zdjęcia pracowników, fotografie z konferencji i sesji naukowych, jubileuszy, wystaw, spotkań towarzyskich i zebrań, m.in. członków Stowarzyszenia Archiwistów Polskich ${ }^{31}$.

Materiały zgromadzone w spuściznach Kazmierza Kaczmarczyka, Czesława Skopowskiego, Jana Szajbla i Kazimiery Chojnackiej stanowią ważne źródło dla zobrazowania działalności ich macierzystego zakładu pracy. Dotychczasowe wykorzystanie tych spuścizn przez badaczy (z wyjątkiem spuścizny Kazimierza Kaczmarczyka) było stosunkowo niewielkie. Po uporządkowaniu i opracowaniu oraz zamieszczeniu inwentarzy na stronie internetowej PAN Archiwum w Warszawie Oddziału w Poznaniu zainteresowanie omówionymi spuściznami powinno być zdecydowanie większe. Dokumentacja zgromadzona w tych zespołach - plany, sprawozdania, zarządzenia, korespondencja służbowa, pisma okólne itp. - uzupełniają w sposób istotny materiały zgromadzone w Archiwum Państwowym. Nie mniej ważnym źródłem są fotografie - nierzadko unikalne - przedstawiające pracowników, poszczególne pracownie, gmachy, konferencje i sesje naukowe, spotkania towarzyskie i uroczystości jubileuszowe. Ponadto należy wymienić notatki osobiste i wspomnienia, gdzie także podejmowane są wątki funkcjonowania archiwum.

27 PANAWOP, Materiały Kazimiery Chojnackiej (1923-2010) P. III-141, j.a. 29. Archiwum Państwowe w Poznaniu.

${ }^{28}$ Tamże, j.a. 31. Archiwum Państwowe w Poznaniu.

${ }^{29}$ Tamże, j.a. 32. Archiwum Państwowe w Poznaniu.

30 Tamże, j.a. 33. Archiwum Państwowe w Poznaniu.

${ }^{31}$ Tamże, j.a. 51. Archiwum Państwowe w Poznaniu. 


\section{Bibliografia}

\section{Źródła archiwalne}

Polska Akademia Nauk Archiwum w Warszawie Oddział w Poznaniu

Materiały Kazimierza Kaczmarczyka (1878-1966), sygn. P III-35

Jednostki:

158. Archiwum Państwowe w Poznaniu.

159. Archiwum Państwowe w Poznaniu.

160. Archiwum Państwowe w Poznaniu.

161. Archiwum Państwowe w Poznaniu.

171. Komisja Odbiorczo-Zdawcza do wymiany akt z Niemcami.

172. Delegacja Polska do wykonania układu archiwalnego polsko-austriackiego.

245. Uroczystość pożegnania w Archiwum Państwowym w Poznaniu 30 kwietnia $1953 \mathrm{r}$.

252. Praca w Archiwum Państwowym w Poznaniu, ze współpracownikami, ze zjazdów i konferencji.

260. Osoby i instytucje A.

\section{Materiały Czesława Skopowskiego (1906-1991), sygn. P III-66}

Jednostki:

2. Z dziejów Archiwum Państwowego w Poznaniu. Wybór źródeł z lat 1866-1965.

3. Dzieje Poznania i Województwa Poznańskiego (w granicach z 1974 r.). Informator o materiatach archiwalnych, t. 2.

4. Dzieje Poznania i Województwa Poznańskiego (w granicach z 1974 r.). Informator o materiałach archiwalnych, t. 2.

5. Dzieje Poznania i Województwa Poznańskiego (w granicach z 1974 r.). Informator o materiatach archiwalnych, t. 2.

6. Dzieje Poznania i Województwa Poznańskiego (w granicach z 1974 r.). Informator o materiatach archiwalnych, t. 2.

7. Dzieje Poznania i Województwa Poznańskiego (w granicach z 1974 r.). Informator o materiatach archiwalnych, t. 2.

8. Dzieje Poznania i Województwa Poznańskiego (w granicach z 1974 r.). Informator o materiatach archiwalnych, t. 2.

9. Dzieje Poznania i Województwa Poznańskiego (w granicach z 1974 r.). Informator o materiatach archiwalnych, t. 2.

10. Dzieje Poznania i Województwa Poznańskiego (w granicach z 1974 r.). Informator o materiałach archiwalnych, t. 2.

11. Dzieje Poznania i Województwa Poznańskiego (w granicach z 1974 r.). Informator o materiałach archiwalnych, t. 2.

14. Archiwum Państwowe w Poznaniu.

18. Archiwum Państwowe w Poznaniu.

19. Archiwum Państwowe w Poznaniu.

21. Archiwum Państwowe w Poznaniu.

22. Archiwum Państwowe w Poznaniu.

24. Archiwum Państwowe w Poznaniu.

27. Archiwum Państwowe w Poznaniu.

29. Archiwum Państwowe w Poznaniu.

30. Archiwum Państwowe w Poznaniu.

50. Moje wspominki. 
Materiały Jana Szajbla (1926-1973), sygn. P III-54 Jednostki:

49. Archiwum Państwowe w Poznaniu.

50. Archiwum Państwowe w Poznaniu.

53. Archiwum Państwowe w Poznaniu.

54. Archiwum Państwowe w Poznaniu.

Materiały Kazimiery Chojnackiej (1923-2010) P III-141

Jednostki:

29. Archiwum Państwowe w Poznaniu.

31. Archiwum Państwowe w Poznaniu.

32. Archiwum Państwowe w Poznaniu.

33. Archiwum Państwowe w Poznaniu.

51. Archiwum Państwowe w Poznaniu.

Opracowania

Skopowski C., Materiały do dziejów Archiwum Państwowego w Poznaniu, „Archeion” 1968, t. 50, s. 143-155.

Jarosław Matysiak

\title{
Materiały do dziejów Archiwum Państwowego w Poznaniu w świetle spuścizn z zasobu PAN Archiwum w Warszawie Oddział w Poznaniu
}

\begin{abstract}
Streszczenie
W artykule przedstawiono spuścizny czterech pracowników Archiwum Państwowego w Poznaniu, przechowywane w zasobie PAN Archiwum w Warszawie Oddział w Poznaniu - dyrektorów placówki: Kazimierza Kaczmarczyka, Czesława Skopowskiego i Jana Szajbla, oraz kierownika Pracowni Konserwacji materiałów archiwalnych Kazimiery Chojnackiej. W tekście przedstawiono okoliczności przejęcia spuścizn przez PAN Archiwum w Warszawie Oddział w Poznaniu, omówiono materiały dotyczące Archiwum Państwowego w Poznaniu i działalności autorów spuścizn w okresie pracy w tymże archiwum.
\end{abstract}

Słowa kluczowe: Archiwum Państwowe w Poznaniu, Chojnacka Kazimiera, Kaczmarczyk Kazimierz, PAN Archiwum w Warszawie Oddział w Poznaniu, Skopowski Czesław, spuścizny, Szajbel Jan 
Jarosław Matysiak

\title{
Materials regarding the history of the State Archive in Poznan in the light of the legacies from the collection of the Archive of the Polish Academy of Sciences in Warsaw, Poznań branch
}

\begin{abstract}
The article presents the legacies of four employees of the State Archive in Poznań, kept in the collection of the Archive of the Polish Academy of Sciences in Warsaw, Poznan branch, namely the directors of the office: Kazimierz Kaczmarczyk, Czesław Skopowski, and Jan Szajbel, as well as Kazimiera Chojnacka, the head of the Archive Materials Preservation Lab. The text presents the circumstances in which these legacies were taken over by the Archive of the Polish Academy of Sciences, Poznań branch, and discusses the materials concerning the State Archive in Poznań and the activity of the authors of the legacies while they had worked in this archive.
\end{abstract}

Keywords: State Archive in Poznań, Chojnacka Kazimiera, Kaczmarczyk Kazimierz, Archive of the Polish Academy of Sciences in Warsaw, Poznań branch, Skopowski Czesław, legacies, Szajbel Jan 